\title{
USES OF SEAWEED AND ITS APPLICATION TO HUMAN WELFARE: A REVIEW
}

\author{
MITALI PRIYADARSINI PATIa, SATYABRATA DAS SHARMA*a,b, LAKSHMAN NAYAKa ${ }^{a}$, CHITA RANJAN PANDA
}

aDepartment of Marine Sciences, Berhampur University, Odisha, India, bCSIR-Institute of Minerals and Materials Technology (IMMT), Council of Scientific and Industrial Research, Bhubaneswar, Odisha, India

Email: sbdsharma1984@gmail.com

Received: 11 May 2016 Revised and Accepted: 12 Aug 2016

\begin{abstract}
Seaweed research has been carried out for more than seven decades by many research workers. Research has been done separately in different aspects accordingly to our need. The main objective of the present review is to gather information relating to nutritional, pharmacological, clinical, biochemical, industrial uses and its application to human welfare. Seaweeds have a high concentration of essential vitamins, trace elements, proteins, lipids, polysaccharides, enzymes, and minerals as compared to terrestrial foodstuffs. These plants have been a source of food, fodder, medicine, cosmetics, energy, fertilizer and are used for industrial production of agar and alginate. Their recent utilization increases in poultry due to their nutritive value. In the present scenario, it is being used for wastewater treatment such as treatment of wastewater to reduce nitrogen and phosphorus containing compounds. This review work is an attempt to highlights all the relevant application and uses of seaweeds and its products. Finally, this paper would be helpful to a common man to know and aware about such a great living resources which is present in and around us.
\end{abstract}

Keywords: Seaweeds, Application, Human Welfare, Review

(C) 2016 The Authors. Published by Innovare Academic Sciences Pvt Ltd. This is an open access article under the CC BY license (http://creativecommons. org/licenses/by/4. 0/) DOI: http://dx.doi.org/10.22159/ijpps.2016v8i10.12740

\section{INTRODUCTION}

Uses of Seaweed have been cited as early as 2500 y ago in Chinese literature [1]. It is being used in worldwide because it contains vitamins, minerals, and fiber. For at least 1,500 y, the Japanese were using a mixture of raw fish, sticky rice, and other ingredients in a seaweed called Nori. In Europe and North America, it has been used for the effectiveness of seaweeds on human health. It has been suggested that amongst other herbal products, seaweeds have curative powers for the treatment of tuberculosis, arthritis, colds and influenza. In earlier times, the therapeutic uses of seaweeds were limited to only traditional and folk medicines [2]. At the end of 1990s, the discoveries of bioactive compounds were made by using marine bacteria, invertebrates and algae [3]. Seaweed broadly says algae are a cheap source in the preparation of new chemicals followed by other marine invertebrates [4]. Seaweed played a milestone in pharmaceutical industries as well as modern biology during the year 1980 to 1995 .

Many types of seaweed contain anti-inflammatory and antimicrobial agents. Their known medicinal effects have been taking for thousands of years; the ancient Romans used them to treat wounds, burns, and rashes. Anecdotal evidence also suggests that the ancient Egyptians may have used them as a treatment for breast cancer. Certain seaweeds possess powerful cancer-fighting agents that researchers hope will eventually prove effective in the treatment of malignant tumors and leukemia in people. While dietary soy was long credited for the low rate of cancer in Japan, this indicator of robust health is now attributed to dietary seaweed. These versatile marine plants and algae have also contributed to economic growth. In this review article, we have discussed a detailed account of study related to different uses and application of seaweed from ancient time to the modern era. We have covered an extensive study and information of seaweed and its uses with special reference to its nutritive value, medicinal property, pharmaceutical activity, pharmacology and industrial uses. The database contains more than 90 articles which include reviews, case study, $\mathrm{Ph}$. D research, research article, annual reports and much more current research.

\section{Seaweed resources}

India is located on $08.04-37.06 \mathrm{~N}$ and $68.07-97.25 \mathrm{E}$, a tropical South Asian country has a stretch of about $7500 \mathrm{~km}$ coastline, excluding its island territories with 2 million $\mathrm{km}^{2}$ Exclusive Economic Zone (EEZ) and nine maritime states (table 1).
Approximately, 271 genera and 1153 species of marine algae, including forms and varieties have been enumerated till date from the Indian waters [5]. Seaweeds are macroscopic algae (nonflowering stemless water plant in Oriya Shaibala) found attached to the solid bottom substrate of rocks, dead corals, pebbles, shells and other plant materials. The seaweeds are found in relatively shallow coastal waters, estuaries, intertidal and deep sea areas up to 180 meters depth. Generally, they are classified into Chlorophyceae (green algae), Phaeophyceae (brown algae) and Rhodophyceae (red algae). There are more than 10000 kinds of seaweeds with a potential of 7.5-8 million tons (wet weight) which are being produced along the coastal regions of the world [6]. About 40,000 tonnes of seaweeds are being exploited for the production of algin and agar every year. Review on the seaweed resources, cultivation and its utilization from different Indian coastal water has well documented by Subba Rao [5]. He also gave a long review on the present with past scenario. Seaweed resources along the Indian coast have listed in table 1 . The distributions of species encountered during the surveys are represented in table 2 . During these surveys, total standing crop varied from $6,77,308.87$ to $6,82,758.87$ tons (fresh weight) along the Indian coast. The seaweeds spreads along the Indian coastline and its nine maritime states and islands (Gujarat-1700, Maharashtra-572, Goa-104, Karnataka-280, Kerala560, Tamil Nadu-980, Andhra Pradesh-960, Orissa-432, West Bengal-280, Andaman and Nicobar Islands-1500 (approx.), Lakshadweep Islands-120 (approx.) in $\mathrm{km}$, table 3). The places of algal interest along coastal states of India are noted in the table. 3.

\section{Nutritional value and biochemical composition of seaweed}

Seaweeds are nothing but the wealth of Ocean or we can say that these are the marine living resources. It's a good source of minerals, vitamins, proteins, carbohydrates and fibers [36]. The minerals like sodium, calcium, magnesium, potassium, chlorine, sulphur, phosphorus and micronutrients such as iodine, iron, zinc, copper, selenium, molybdenum, fluoride, manganese, boron, nickel and cobalt are plenty in different species of seaweed. Apart from that, it's a good source of iodine generally highest in brown seaweed. The calcium and protein content varies from species to species but has low-fat content. Generally, green and red seaweed has high protein content (up to $30 \%$ ), whereas lower (up to 15\%) was found in brown seaweeds [37]. But during the Mandapam coast survey, the highest protein content was found in brown algae as compared to 
green and red. This may also be varied depending on the habitat and according to the depth. Protein content varies among different genera and also in different species of the same genus which has been cited in table 4 .

Table 1: Seaweed resources studied by different authors along the Indian coast along the Indian coast

\begin{tabular}{|c|c|c|}
\hline Area & Annual yield in tonnes (fresh wt.) & Source \\
\hline \multicolumn{3}{|l|}{ Gujarat } \\
\hline Gulf of Kutch & $1,00,250^{*}$ & Desai1967 [7] \\
\hline Gulf of Kutch & 4000 & Chauhan and Krishnamurthy1968[8] \\
\hline $\begin{array}{l}\text { Okha to Dwarka and } \\
\text { Vumani reef }\end{array}$ & Vumani reef & Bhandari and Trivedi1975[9] \\
\hline Adhatra reef & 60 & Sreenivasa Rao et al. 1964[10] \\
\hline Saurashtra & $282-610$ & Chauhan and Mairh1978[11] \\
\hline \multicolumn{3}{|l|}{ Maharashtra } \\
\hline Konkan & 315 & Chauhan1978[12] \\
\hline Entire coast & 20,000 & Untawale 1979 et al.[13] \\
\hline \multicolumn{3}{|l|}{ Goa } \\
\hline Donapaula to Chapora & 255 & Untawale 1983et al.[14] \\
\hline Kerala & 1000 & Chennubhotla 1988et al.[15] \\
\hline \multicolumn{3}{|l|}{ Tamil Nadu } \\
\hline Madras coast & 690 & Umamaheswara Rao1973[16] \\
\hline Cape Comorin to Colachal & 5 & Koshy and John1948[17] \\
\hline Calimare to Cape & 66,000 & Chacko and Malu Pillai1958[18] \\
\hline \multicolumn{3}{|l|}{ Comorin } \\
\hline Pamban & 1000 & Verma and Krishna Rao1962[19] \\
\hline Palk Bay & 631 & Umamaheswara Rao1973[16] \\
\hline South east coast & 20,535 & c. f. Untawale et al.1983[14] \\
\hline Gulf of Mannar & $33,000 *$ & Desai1967[7] \\
\hline Entire coast (intertidal) & 22,044 & Anon.1978[20] \\
\hline Entire coast (subtidal) & 75,375 & Kaliaperumal et al.1998[21] \\
\hline Andhra Pradesh & 7500 & Anon.1984[22] \\
\hline \multicolumn{3}{|l|}{ Orissa } \\
\hline Chilka lake & 5 & Mitra1946[23] \\
\hline Chilka lake & $2,69,700^{*}$ & Rath and Adhikari, 2004 [24] \\
\hline Lakshadweep & $4955-10,077$ & Anon.1979[25] \\
\hline Gujarat & 12.15 & Bhandari and Trivedi1975[9] \\
\hline \multicolumn{3}{|l|}{ Andaman } \\
\hline South Andaman & 19,111 & Muthuvelan et al.2001[26] \\
\hline Middle and North & 6817 & Muthuvelan et al.2001[27] \\
\hline \multicolumn{3}{|l|}{ Andaman } \\
\hline Little Andaman & 120 & Gopinathan and Panigrahy1983[28] \\
\hline Drift seaweeds & 1260.18 & Krishnamurthy1969[29] \\
\hline Total & $6,77,308.87$ to $6,82,758.87$ & \\
\hline
\end{tabular}

Source: Subba Rao* and Vaibhav A. Mantri, 2006 [5], (All values are in tons (fresh weight)

Table 2: Species composition encountered during different surveys along the Indian coast

\begin{tabular}{|c|c|c|c|c|c|c|}
\hline State & Green & Brown & Red & Blue-green & Total Source & Literature \\
\hline Gujarat & 29 & 24 & 39 & Nil & 92 & Chauhan and Mairh 1978[11] \\
\hline Gujarat (subtidal) & Nil & Nil & Nil & Nil & 35 & Dhargalkar and Deshmukh 1996[30] \\
\hline Maharashtra & 11 & 11 & 14 & Nil & 36 & Chauhan 1978[12] \\
\hline Karnataka* & 16 & 10 & 16 & 1 & 43 & Agadi 1985[31] \\
\hline Kerala & 13 & 3 & 17 & 2 & 35 & Chennubhotla et al.1988 [15] \\
\hline Tamil Nadu (intertidal) & 113 & 83 & 225 & 5 & 426 & Anon.1978[20] \\
\hline Tamil Nadu (subtidal) & 8 & 8 & 12 & 1 & 29 & Kaliaperumal et al.1998[21] \\
\hline Andhra Pradesh & 23 & 7 & 34 & 1 & 65 & Anon.1984[22] \\
\hline West Bengal* & 9 & Nil & 5 & Nil & 14 & Mukhopadhyay and Pal 2002 [32] \\
\hline Orissa* (Chilka lake) & 8 & Nil & 6 & Nil & 14 & Sahoo et al.2003[33] \\
\hline Lakshadweep Islands & 33 & 10 & 39 & Nil & 82 & Anon.1979[25] \\
\hline Great Nicobar Island* & 18 & 15 & 18 & Nil & 51 & Ravindran et al.2004[34] \\
\hline South Andaman Islands & 29 & 15 & 11 & Nil & 55 & Muthuvelan et al.2001[27] \\
\hline Middle and North Andaman Islands & 11 & 11 & 5 & Nil & 27 & Muthuvelan et al.2001[26] \\
\hline Diu* & 27 & 14 & 29 & Nil & 70 & Mantri and Subba Rao 2005[35] \\
\hline
\end{tabular}

*Qualitative survey only, Source: Subba Rao* and Vaibhav A. Mantri $(2006)^{5}$ 
Table 3: Distribution of seaweeds in different maritime state/union territories along the Indian coast

\begin{tabular}{lll}
\hline State & Coastline (km) & Places of algal interest \\
\hline Gujarat & 1700 & Okha (22.15 N, 69.1 E), Dwarka (22.14 N, 69.1 E) \\
Maharashtra & 572 & Malvan (16.03 N and 73.30 E) \\
Goa & 104 & Panaji (15. 03 N and 73. 55 E) \\
Karnataka & 280 & Karwar (14.48 N and 74.11 E) \\
Kerala & 560 & Quilon (8.54 N and 76.38 E), Varakala (8.28 N and 76.55 E) \\
Tamil Nadu (including Pondicherry) & 980 & Krusadai Island (9.14 N and 79.13 E), Idinthakarai (8.10 N and 77.43 E) \\
Andhra Pradesh & 960 & Visakhapatnam (17.44 N and 83.23 E), Pulicat lake (13.20-13.40 N and 80.14- \\
& & 80.15 E) \\
Orissa & 432 & Chilka lake (19.50 N and 85.30 E) \\
West Bengal & 280 & Sundarbans (21.33-22.45 N and 88.06-89.05 E) \\
Andaman and Nicobar Islands & 1500 (approx.) & 6-14 N and 92-94 E \\
Lakshadweep Islands & 120 (approx.) & 8-12 N and 72-74 E \\
\hline
\end{tabular}

Source: Subba Rao* and Vaibhav A. Mantri (2006) ${ }^{5}$

Chlorophyceae members generally have high carbohydrate content than Rhodophyceae and Phaeophyceae [38] but this may also vary according to the species type and habitat. For example; the maximum carbohydrate content was recorded in the green seaweed E. intestinalis $28.58 \%$ and the minimum was found to be $10.63 \%$ in brown seaweed of Dictyota dichotoma [38]. In green seaweed of $U$. lactuca (35.27\%) and E. intestinalis (30.58\%) also contain higher carbohydrate content [39].

The Seaweeds collected from the Maharashtra coast and Kovalam coast of India noted the maximum value of carbohydrate content in Rhodophyceae than in Phaeophyceae and Chlorophyceae. This may be due to higher phycocolloid content in their cell walls [40]. In other cases, the Phaeophycean group gas the high carbohydrate content followed by green algae and red algae. The order of carbohydrate content in Mandapam coast (table 5) was such as Turbinaria conoides (23.9\%), Sargassum tenerimum (23.55\%), Sargassum wightii $(23.50 \%)$ followed by green alga E. intestinalis (23.84\%) and the red algae H. valentiae $(23.60 \%)$, Acanthophora spicifera $(23.54 \%)$. The minimum carbohydrate content was observed from green alga Codium tomentosum (20.47\%) followed by brown algae Padina gymnospora (21.88\%), Colpomenia sinuosa $(22.46 \%)$ and the red alga Gracilaria folifera (22.32\%) [41].

Marine macroalgae contained a low amount of lipids. In Mandapam coastal survey (table 6), maximum lipid content was observed from E. clathrata (4.6\%) followed by G. folifera (3.23\%), C. tomentosum $(2.53 \%)$, C. sinuosa $(2.337 \%)$ and S. wightii (2.337\%). The minimum lipid concentration was recorded from $E$. intestinalis $(1.33 \%)$ followed by P. gymnospora (1.4\%), S. Tenerimum $(1.46 \%)$ and $U$. lactuca $(1.6 \%)[41]$.

Table 4: Biochemical composition of different seaweed species (protein in \%) from various coasts of India

\begin{tabular}{|c|c|c|c|}
\hline Family & Seaweed species & Protein & Area/Habitat \\
\hline \multirow[t]{5}{*}{ Phaeophyceae (Brown algae) } & Padina gymnospora & 17.08 & Mandapam coastal regions \\
\hline & Sargassum tenerimum & 12.42 & Mandapam coastal regions \\
\hline & Sargassum coriifolium & 16.07 & Bay of Bengal, St. Martin's Island \\
\hline & Padina tenuis & 8.32 & \\
\hline & Turbinaria ornate & 14.68 & Mandapam coastal regions \\
\hline \multirow{6}{*}{ Chlorophyceae (Green algae) } & Ulva lactuca & 3.25 & Mandapam coastal regions \\
\hline & Ulva rigida & 6.64 & Chilika \\
\hline & Enteromorpha intestinalis & 16.38 & Mandapam coastal regions \\
\hline & Codium tomentosum & 6.13 & Mandapam coastal regions \\
\hline & U. rigida & 28.06 & Sea of Marmara \\
\hline & U. lactuca & 27.7 & Sea of Marmara \\
\hline \multirow[t]{5}{*}{ Rhodophyceae (Red Algae) } & Gracilaria folifera & 6.98 & Mandapam coastal regions \\
\hline & Gracilaria verrucosa & 9.47 & Mandapam coastal regions \\
\hline & Hypnea valentiae & 8.34 & Mandapam coastal regions \\
\hline & Kappaphycus alvarezii, & 18.78 & Rameshwaram \\
\hline & Gracillari canaliculata & 8.51 & Massawa region, Red sea \\
\hline
\end{tabular}

Source: Compiled From Published Reports

Table 5: Biochemical composition of different seaweed species (Carbohydrate in \%) from various coasts of India

\begin{tabular}{|c|c|c|c|}
\hline Family & Seaweed species & Carbohydrate & Area/Habitat and source \\
\hline \multirow[t]{6}{*}{ Phaeophyceae (Brown algae) } & Dictyota dichotoma & $10.63 \%$ & Tuticorin coast (Parthiban, 2013)[38] \\
\hline & Turbinaria conoides & 23.9 & Mandapam coast (Manivannan, 2008)[41] \\
\hline & Sargassum tenerimum & 23.55 & Mandapam coast (Manivannan, 2008) [41] \\
\hline & Sargassum wightii & 23.50 & Mandapam coast (Manivannan, 2008)[41] \\
\hline & Padina gymnospora & 21.88 & Mandapam coast (Manivannan, 2008)[41] \\
\hline & Colpomenia sinuosa & 22.46 & Mandapam coast(Manivannan, 2008)[41] \\
\hline \multirow[t]{5}{*}{ Chlorophyceae (Green algae) } & E. intestinalis & 28.58 & Tuticorin coast (Parthiban, 2013)[38] \\
\hline & & 30.58 & Sunderban (Chakraborty and Santra 2008)[39] \\
\hline & & 23.84 & Mandapam coast(Manivannan, 2008)[41] \\
\hline & U. lactuca & 35.27 & Sunderban (Chakraborty and Santra 2008)[39] \\
\hline & Codium tomentosum & 20.47 & Mandapam coast (Manivannan, 2008)[41] \\
\hline \multirow[t]{3}{*}{ Rhodophyceae (Red algae) } & H. valentiae & 23.60 & Mandapam coast (Manivannan, 2008)[41] \\
\hline & Acanthophora spicifera & 23.54 & mandapam coast (Manivannan, 2008)[41] \\
\hline & Gracilaria folifera & 22.32 & mandapam coast (Manivannan, 2008) [41] \\
\hline
\end{tabular}

Source: Compiled from Published Reports 
Table 6: Biochemical composition of different Seaweed species (Lipid in \%) from various coasts of India

\begin{tabular}{|c|c|c|c|}
\hline Family & Seaweed species & Lipid in \% & Area/Habitat and source \\
\hline \multirow[t]{4}{*}{ Phaeophyceae (Brown algae) } & C. sinuosa & 2.337 & Mandapam coast, Manivannan et al. 2008[41] \\
\hline & S. wightii & 2.337 & Mandapam coast, Manivannan et al. 2008[41] \\
\hline & P. gymnospora & 1.4 & Mandapam coast, Manivannan et al. 2008[41] \\
\hline & S. Tenerimum & 1.46 & Mandapam coast, Manivannan et al. 2008[41] \\
\hline \multirow[t]{6}{*}{ Chlorophyceae (Green algae) } & E. clathrata & 4.6 & Mandapam coast, Manivannan et al. 2008[41] \\
\hline & E. intestinalis & 1.33 & Mandapam coast, Manivannan et al. 2008[41] \\
\hline & E. intestinalis & 7.13 & Sunderban, Chakraborthy and Santra (2008) [39] \\
\hline & U. lactuca & 1.6 & Mandapam coast, Manivannan et al. 2008[41] \\
\hline & U. rigida & 12 & Satpati et al. 2011[42] \\
\hline & C. tomentosum & 2.53 & Mandapam coast, Manivannan et al. 2008[41] \\
\hline \multirow[t]{2}{*}{ Rhodophyceae (Red algae) } & G. folifera & 3.23 & Mandapam coast, Manivannan et al. 2008[41] \\
\hline & K. alvarezii & 1.09 & Rajasulochana et al. 2012[43] \\
\hline
\end{tabular}

Source: Compiled from Published Reports

In some study, it was revealed that the lipid content of $U$. rigida is $12 \%$ [42] and in K. alvarezii it was $1.09 \%$ [43]. In India along Tuticorin coast survey, green seaweed E. intestinalis showed the high lipid content (7.13\%) and red seaweed G. verrucosa marked the minimum lipid content [39]. Seaweeds contain both water-and fatsoluble vitamins. The vitamins like B1, B2, B3, B6, B8, B9, B12, C and $\mathrm{E}$ are available in significant amount in different species of algae.

\section{Seaweed as food}

Seaweeds are used in many maritime countries, particularly in Asia, Japan, Korea and China as a source of food, industrial applications and for fertilizer. The current uses of seaweeds are as human foods, cosmetics, fertilizers and for the extraction of industrial gums and chemicals. In Japan, kombu and kunbu in Chinese (The common food item with low cost but highly nutritious) is used in the preparation of soups, fish, meat dishes and also as a vegetable with rice. Some seaweed has an excellent dietary content, mainly protein, some carbohydrate, vitamins $\mathrm{A}, \mathrm{B}, \mathrm{B}_{2}$ and $\mathrm{C}$. Besides these a lot of trace elements and minerals, the most prominent of which is iodine. An additional advantage is that it is low in calories and very suitable for vegetarians of all kinds. As the seaweed has high protein content as it is being used by many of the countries like Japan, China, Korea, Malaysia, Thailand, Indonesia, Philippines and other South East Asia. Seaweeds like Ulva sp., Enteromorpha sp., Caulerpa sp., Codium sp., Monostroma sp., Sargassum sp., Hydroclathrus sp., Laminaria sp., Undaria sp., Macrocystis sp., Porphyra sp., Gracilaria sp., Eucheuma sp., Laurencia sp. and Acanthophora sp. are used in the preparation of soup, salad and curry [37]. Some of the seaweeds are also taken in dried form.

\section{Seaweed as beauty enhancer}

Algotherapy is a science in which, seaweed extracts are used in health or beauty treatments. Seaweed baths were a widespread feature of seaside resorts at the end of the 19th and beginning of 20 th century in several southern and western locations. Seaweed baths as a treatment for arthritis, rheumatism and other aches and pains. Many companies producing a seaweed powder (made mainly from Ascophyllum nodosum) for beauty and body care products containing seaweed extracts. A number of compounds extracted from seaweeds are thought to be of value in various cosmetic applications and some are now becoming commercially important.

\section{Medicinal and pharmacological properties}

From prehistoric times; seaweeds has been widely used as food [44, $45]$ as these are the chief source of vitamins and minerals [46]. The extracts and its products are effective nutritional supplements [47]. Apart from the nutritional support it has also used against various biological diseases like antimicrobial, antiviral, antifungal, antiallergic, anticoagulant, anticancer, antifouling and antioxidant activities [48]. Yuvaraj [49], described the marine brown alga i. e Sargassum wightii have the anti-tumor, anti-inflammatory, antioxidant and antibacterial activities.

\section{Antioxidant activities}

Seaweeds have good antioxidant properties, which play a major role to fight against various diseases like cancer, chronic inflammation, atherosclerosis and cardiovascular disorder and ageing processes [48]. It also prevents the rate of cancer cell formation [50].

\section{To control heart disease and stroke}

Use of seaweed can help in Reduction of plasma cholesterol, which may reduce the risk of cardiovascular disease [51].

\section{Antimicrobial and antifungal activity}

The methanol crude extracts of Gracilaria corticata having good usefulness against the antimicrobial and antifungal activities. Among different solvent extracts like methanol, acetone, chloroform, and hexane-ethyl acetate, methanol showed the highest antibacterial activity against different pathogenic bacteria such as Staphylococcus aureus, Streptococcus pyogenes, Streptococcus epidermis, Bacillus subtilis and Bacillus cereus, Klebsiella pneumoniae and Enterobacter aerogenes [52]. The Gracilaria corticata, Sargassum wightii and Turbinaria ornate also have a good source of antimicrobial agent [53]. Similarly, ethanol extract showed maximum antibacterial activity against Staphylococcus species as compared to methanol extracts against Escherichia coli, Staphylococcus and Proteus species [54].

\section{Anti-inflammatory property}

Methanol extracts of the seaweeds Undaria pinnatifida and Ulva linza have a better inflammatory activity while tested against mouse ear edema and erythema. Edema was strongly dormant by the seaweeds Undaria pinnatifida and Ulva linza. These two seaweeds also showed the greatest suppression of erythema [55].

\section{Seaweeds as anticancer agents}

Seaweeds are the most important reservoirs of new therapeutic compounds for humans. Different types of seaweed extracts have been experimentally proved to reduce or to destroy the effectiveness of cancer. The dietary intake of seaweed has also been implicated as a potential protective agent in the aetiology of breast cancer [56]. The brown algae Fucus spp. has shown activity against both colorectal and breast cancers [57]. An anticancer effect of different seaweeds on human colon and breast cancers has been well documented by Ghislain et al. 2014[57]. In ancient times, Chinese was used Laminaria sp. in the treatment of cancer and it has also been recorded in ancient ayurvedic texts [58]. Seaweed in a diet plays an active role in reducing the risk of breast cancer and another type of cancer. A series of mechanism in which; cancer could be reduced or retards its rate of growth. It includes reduction of plasma cholesterol, binding of biliary steroids, antioxygenic activity, binding of toxic materials, induction of apoptosis, inhibition of cell adhesion, the addition of important trace minerals to the diet.

\section{Antidiabetic activity}

Aqueous extract of Ulva fasciata was shown a good remarkable difference while treated against diabetic rats as compared to other standard medicine. Abirami, 2013[59] experimented over a $28 \mathrm{~d}$ of oral treatment against infected rats. He found a significant decrease in blood glucose and glycosylated hemoglobin level while pretreatment with aqueous of Ulva fasciata. 


\section{Antiviral activity}

A scientist from many countries of the world showed antiviral activities against human infectious diseases like human immunodeficiency virus (HIV), Herpes simplex virus (HSV) types 1 and 2 and respiratory syncytial virus (RSV) by using Aghardhiella tenera and Nothogenia fastigiata sp. [60-62]. All marine algae seem to have antiviral sulfated polysaccharides. Carrageenans, fucoidans and sulfated rhamnogalactans have substantial antiviral activity against enveloped viruses, such as herpes and HIV. These compounds obstruct the entry of viruses into cells, although other algal fractions have virucidal and enzyme inhibitory activities, or can slow down syncytium formation [63].

\section{Antibiotic activity}

The presence of antagonistic or chemical compounds in algae makes them functional as antibiotics. These compounds are useful against various diseases such as viral, bacterial and fungal [46]. Several experiments and patents were carried out in ancient times by researchers to find out these chemical compounds which basically fall in categories of phaeophyceae, chlorophyceae and rhodophyceae $[64,65]$. The compounds include fatty acids, bromophenols, tannins, phloroglucinol, terpenoids and halogenated compounds [66].

\section{Cellular growth activity}

The compound derived from Eucheuma serra have been successfully implemented on mouse lymphocytes using lectins to stimulate nondividing cell of mitosis [67].

\section{Effects on fertilization and larval development}

The lectin diabolin isolated from Laminaria diabolica causes the development of a fertilized envelope around unfertilized eggs of the sea urchin Hemicentrotus pulcherrimus, thus preventing cleavage $[68,69]$. Terpenoids are also known for their effects on fertilization and subsequent various seaweed-derived compounds affect fertilization and larval or embryonic development in both invertebrates and vertebrates. Premakumara et al. [70] identified a sphingosine derivative from Gelidiella acerosa as a post-coital contragestative agent in studies on pregnant rats and development of embryos. For example, caulerpenyne, a sesquiterpene from Caulerpa taxifolia, affects embryogenesis, larval development and metamorphosis of the sea urchin Paracentrotus lividus [71, 72]. It also interferes with microtubule-dependent events during the first mitotic cycle of sea urchin eggs and affects regulation of intracellular $\mathrm{pH}$ in sea urchin eggs and sea bream hepatocytes $[73,74]$.

\section{Vermifuge activity}

In addition to the antibiotic effect of algal extracts, certain marine algae have been used as vermifuges (killing intestinal worms, such as Ascaris) or anthelmintics [46, 75]. The kainic acid produced from the extract of Digenea (red alga) act as an efficient vermifuge activity against Ascaris worm without causing any side effects to the patient [76].

\section{Antitumor activity}

Compounds extracted from several species of marine blue-green algae have been successfully tested against lymphocytic leukemia and Ehrlich ascites tumor in mice [77].

\section{Anti-ulcer wound healing and hepatoprotective activities}

Kulandhaisamy and Murugan [78] has experimentally proved and reported seaweeds like Gracilaria crassa, Laurencia papillosa and Turbinaria ornata have a good antiulcer, wound healing and hepatoprotective activities. In their study, they found L. papillosa showed highest protection (81\%) followed by Gracilaria crassa $(76 \%)$ against gastric as comparable to the standard drug ranitidine (90\%).

\section{Goitre treatment}

Goitre disease is caused due to the low concentration of iodine in food which results in physical retardation in people. We can overcome to this disease by the use of marine algae as these are tremendous sources of iodine. Vitamin deficiency can also be prevailing by use of seaweed supplements in the diet [79].

\section{Industrial use}

Agar or "agar-agar" which is well known in southeast Asia but it was discovered in Japan, where it is popularly known as "kanten". Agar is used as a solid substrate for the growth of bacteria and fungi. Major seaweeds genera which are being involved for the production of agar includes; Ahnfeltiopsis, Gelidium, Gelidiella, Gracilaria, Pterocladiella and Pterocladia. Agar has been produced by most of the countries comprise Argentina, Canada, Chile, China, France, India, Indonesia, Japan, Madagascar, Mexico, Morocco, Namibia, New Zealand, Peru, Portugal, Russia, South Africa, Spain, Thailand, and the USA. No modern microbiological laboratory in the world can survive without agar, and no reasonable alternative has been found even in with today's technological advances. The highest quality of agar and its derivative called agarose comes from red algae belonging to family Gelidiaceae. While other lower-quality agars are mainly found in other families, particularly the Gracilariaceae. Seaweed industrial gums, also known as 'seaweed hydrocolloids,' extracted from seaweeds fall into three categories: alginates (derivatives of alginic acid), agars and carrageenans. Alginates are extracted solely from brown seaweeds while agars and carrageenans are extracted only from red seaweeds.

\section{Agar agar}

It is commonly used as in inert carrier of nutrients in Biotechnology and microbiology. This can also used in cakes, chocolates, candies, jellies, jams, juices, coffee, wafers, liquors, salad dressing etc. As a stabilizer, it is being used in sauces, a solidifying agent, emulsifier and laxative. In the manufacture of photographic film, paint, batteries, graphite, glue etc.

\section{Alginates}

Alginate is used to improve the quality of paper texture. It is being used as a potential ingredient in frozen foods, stabilizer in ice creams, reactive base in reactive dye printing of textiles. Alginates also widely used in many pharmaceutical industries as a stabilizer. It acts as an emulsifier for many food products in food industries such as an additive in instant food drinks, to keep food particle liquid in the mixture. It also helps as natural latex creaming and thickening of rubber [80-82].

\section{Renewable energy supplier}

The unexploited seaweed biomass is utilized for the production of biogas and it has been practiced in most of the developed countries [83]. The biogas used for different purposes such as cooking, heating or electricity generation.

\section{Seaweed as food complement for farm animals}

Seaweeds are used for complementary food to the farm animals such as cattle, poultry and other farm animals. Seaweed builds resistance to disease by ensuring a complete balance of micronutrients. They also assist in decreasing the rate of mastitis and cow fever [84]. It also improves fat level and iodine content in milk and in yield milk products. Seaweed also enhances the fertility and birth rate of animals and also improves yolk colour in eggs [85]. The food prepared from the species of Gracilaria, Gelidiella, Hypnea and Sargassum is added as feed for fish and prawn culture. The feed has enriched with minerals, amino acids and carbohydrates which promotes for maintaining water quality in aquaculture [86]. Seaweeds can also be employed as water disinfectant in aquaculture as it recycles fish waste polluted water [83].

\section{Seaweed used as organic manure}

Seaweed has been widely used as manure. In common; seaweed has sufficient amount of micronutrients, growth promoting hormones, potassium, nitrogen and humic acids. Presences of such materials in seaweed make them as excellent fertilizer [83]. Species of Laminaria, Ascophyllum, Sargassum are used as an organic manure and are biodegradable, non-toxic, non-polluting and non-hazardous to 
human, animals and birds. Besides this it increases the soil fertility and has good moisture holding capacity.

\section{Seaweeds in domestic sewage treatment}

Seaweeds are capable of removing most of the nutrients efficiently from the waste waters. Under standard treatment process, seaweed can remove nutrients like nitrogen and phosphorus from domestic sewage. In aquaculture, it is being used to avert the effluent by shrimp culture which helps to prevent from eutrophication. The red seaweeds Gracilaria verrucosa have the higher efficiency to remove BOD and COD level whereas green seaweed Ulva fasciata has more efficiency for removal of ammonia [87].

\section{Wastewater treatment}

In modern times the seaweeds are used in the treatment of sewage and some agricultural wastes to reduce nitrogen and phosphorus containing compounds before the release of these treated waters into rivers or oceans. In other words, we can say to check eutrophication in freshwater, brackish water and marine environment. Eutrophication is the enrichment or excess deposition of nutrients in terms of minerals, nitrogen and phosphorus containing materials. Eutrophication can occur naturally, but it can be accelerated by allowing water, rich in dissolved fertilizers, to seep into nearby lakes and streams, or by the introduction of sewage effluent into rivers and coastal waters. This will lead to the unwanted and excessive growth of aquatic or marine plants. Another important feature of many types of seaweed is their ability to take up more phosphorus than they require for maximum growth. Intertidal and estuarine species are the most tolerant, especially green seaweeds such as species of Enteromorpha and Monostroma.

\section{Removal of toxic metals from Industrial wastewater}

The other application is for the removal of toxic metals such as copper, nickel, lead, zinc and cadmium from industrial wastewater. Metals come either from natural sources or from mining or disposal of industrial wastes. Brown seaweeds such as Sargassum, Laminaria and Ecklonia and the green seaweeds Ulva and Enteromorpha have more efficient to accumulate of toxic metals. So it's a biological indicator of heavy metal pollution.

\section{other uses}

Seaweeds are not only used in the pharmacological and clinical application but also used in Poultry and cattle farming. It is a primary source of food for many marine organisms. It has a good water-binding capacity. It increases texture; improve fat replacement, product yields and helps in analogue seafood binding. It is being used in Dairy products e. g. chocolate milk, frozen desserts, UHT milks, flans, puddings, low-fat cheese and cheese analogue. It also provides cocoa suspension, milk stability, emulsion stability and for milk gelling. Its other uses include; cold milk powders, diet powder mixes and nutritional beverage mixes. In toothpaste, it provides structure without masking flavours, resistant to enzymatic breakdown.

In pet foods, it binds water, provides structure and prevents fat separation in canned, retorted products. Its wider use includes controlled release products e. g. air freshener gels. It provides structure and controlled release of active ingredients such as perfume in a water gel base. The different uses of various seaweeds are represented in table 7 .

Table 7: The list of some commercially important seaweed used for different purposes

\begin{tabular}{|c|c|c|c|c|c|}
\hline Species & Food & Feed & Industrial uses & Medicine & Fertiliser \\
\hline Gracillaria corticata & + & + & + & - & - \\
\hline Sargassum cinereum & - & - & + & + & + \\
\hline Sargassum ilicifolium & - & + & + & + & + \\
\hline Porphyra vietnamensis & + & + & - & - & - \\
\hline Colpomenia sinuosa & - & - & + & - & + \\
\hline Spatoglossum asperum & - & - & + & - & + \\
\hline Padina tetrastromatica & - & - & + & - & + \\
\hline Caulerpa sertularioides & + & + & - & - & - \\
\hline Stoechospermum & - & - & + & - & + \\
\hline \multicolumn{6}{|l|}{ Marginatum } \\
\hline Chaetomorpha media & + & + & - & - & + \\
\hline Laminaria digita & - & - & + & + & - \\
\hline Jania adhaerens & - & - & - & + & - \\
\hline Laurencia papillosa & + & + & + & - & + \\
\hline Eucheuma uncinatum & + & + & + & - & - \\
\hline Hypnea musciformis & + & + & + & - & - \\
\hline Dictyopteris australis & - & - & + & - & + \\
\hline Centroceros clavulatum & + & - & + & - & - \\
\hline Chondrus crispus & + & - & + & - & - \\
\hline Gelidiella acerosa & - & - & + & - & - \\
\hline Amphiroa fragilissima & + & - & - & - & + \\
\hline Macrocystis pyrifera & - & - & + & + & + \\
\hline Hydroclathrus clathratus & - & - & + & - & + \\
\hline Ulva fasciata & + & + & - & + & - \\
\hline Dictyota dichotoma & + & + & + & - & - \\
\hline Enteromorpha compressa & + & + & - & + & - \\
\hline Cladophora fascicularis & + & + & - & - & - \\
\hline Monostroma oxyspermum & + & + & - & - & - \\
\hline Codium fragile & + & + & - & + & - \\
\hline
\end{tabular}

Source: Compiled from Published Reports

\section{Role of seaweeds in marine ecosystem}

Apart from these above uses, seaweeds play a major role in maintenance and balancing of marine food chain. It provide nutrients and energy for marine animals either directly when fronds are eaten or indirectly when it decompose into fine particles and are taken up by filter-feeding animals. Beds of seaweed provide shelter and habitat of coastal animals for whole or part of their lives.

They are important nurseries for numerous commercial species such as the rock lobster, abalone and green-lipped mussel. 


\section{CONCLUSION}

This review article involved a thorough study of different literatures from India as well as from world scenario. This paper describes the detail account on the seaweed uses from ancient times to modern era. Seaweeds are chief resource of essential vitamins, trace elements, proteins, lipids, polysaccharides, enzymes and minerals. Although seaweed and its products have a wide range of application in pharmaceutical, clinical and industrial sector but regular uptake of seaweed may not be safe as it could be contaminated by heavy metals. The brown algae i.e. Bladderwrack is a potential source of heavy metals and with high iodine content which may lead to toxic. Regular uptake of bladderwrack may result in the abnormalities in thyroid, acne-type skin lesions, increased salivation, stomach irritation and may also and may affect the blood sugar level. There is no side effect when red marine algae is used whereas a few side effects have been reported from green algae as it can accumulate heavy metals from the surrounding contaminated water and could be toxic to body[88]. Medicinal plants and seaweeds available in the marine environment is the ideal place for the discovery of novel molecules with various biological activities such as antibacterial, anticancer, antifungal, antidiarrhoeal, analgesics, antidiabetic, antiinflammatory and antioxidant agent [89]. Red and brown seaweeds are considered as a rich source of bioactive secondary metabolites such as steroids, flavonoids, glycosides, alkaloids and insecticides related active metabolites are of great medicinal value [90]. Therefore we can use these herbal plant and their products to cure different diseases as it has no side effect as compared to allopathic drugs [91].

There are a number of research work have been done on seaweed and their uses from many parts of the world. Most of the work has been done with special reference to its nutritive value, medicinal property, pharmaceutical, pharmacology and industrial uses. The main objective of writing this review is to provide information in all fields related to uses and application of seaweed both in past and present scenario. Coastal area-wise distribution and resources were also made for better understanding. This is an attempt to provide information in the field of science and awareness for a common man about such a great noble resources.

\section{CONFLICT INTERESTS}

\section{Declared none}

\section{REFERENCES}

1. Tseng CK. The past, present and future of phycology in China. Hydrobiologia 2004;512:11-20.

2. Lincoln RA, Strupinski K, Walker JM. Bioactive compounds from algae. Life Chem Rep 1991;8:97-183.

3. Mayer AMS, Lehmann VKB. Marine compounds with antibacterial, anticoagulant, antifungal, anti-inflammatory, anthelmintic, antiplatelet, antiprotozoal, and antiviral activities; with actions on the cardiovascular, endocrine, immune, and nervous systems; and other miscellaneous mechanisms of action. Pharmacologist 2000;42:62-9.

4. Ireland CM, Copp BR, Foster MP, McDonald LA, Radisky DC, Swersey JC. Biomedical potential of marine natural products. Marine Biotechnology, Pharmaceutical, and Bioactive Natural Products: Plenum Press NY; 1993;1:1-43.

5. Subba Rao PV, Mantri A. Indian seaweed resources and sustainable utilization: scenario at the dawn of a new century. Curr Sci 2006;91:164-4.

6. McHugh DJ. A guide to the seaweed industry. FAO Fisheries Technical Paper 2003;441:105.

7. Desai BN. Seaweed resources and extraction of alginate and agar. In: Proceedings of the Seminar on Sea, Salt and Plants, Bhavnagar; 1967. p. 343-1.

8. Chauhan VD, Krishnamurthi V. An estimate of algin-bearing seaweeds in the Gulf of Kutch. Curr Sci 1968;37:648.

9. Bhanderi PP, Trivedi YA. Seaweed resources of Hanumandandi reef and Vumani reef near Okha port, Gujarat. Indian J Mar Sci 1975;4:97-9.

10. Sreenivasa Rao P, lyengar EER, Thivy F. Survey of algin bearing seaweed at Adatra reef. Okha Curr Sci 1964;33:464-5.
11. Chauhan VD, Mairh OP. Report on survey of marine algal resources of saurashtra coast, India. Salt Res Ind 1978;14:21-4.

12. Chauhan VD. Report of the survey of marine algae resources of Maharashtra coast. Salt Res Ind 1978;14:1-10.

13. Untawale AG, Dhargalkar VK, Agadi VV, Jagtap TG. Marine algal resources of Maharashtra coast. Technical Report, National Institute of Oceanography, Goa; 1979. p. 48.

14. Untawale AG, Dhargalkar VK, Agadi VV. List of marine algae from India. Technical Report National Institute of Oceanography, Goa; 1983. p. 42.

15. Chennubhotla VSK, Ramachandrudu BS, Kaladharan P, Dharmaraj SK. Seaweed resources of Kerala coast. Aquat Biol 1988;7:69-4.

16. Umamaheswara Rao M. Seaweed potential of the seas around India. Proc Symp Living Resources of the Sea around India; 1973. p. 687-2.

17. Koshy TK, John CC. Survey of Gracilaria resources of travancore. Dept Res Univ Travancore Rept Septen; 1948. p. 35-3.

18. Chacko PI, Malu Pillai C. Studies on the utilization of the seaweed resources of Madras State. Contrib Mar Biol Stn Krusadai Island Gulf of Mannar 1958;6:1-1.

19. Verma RP, Krishna Rao K. Algal resources of Pamban area. Indian J Fish 1962;9:205-1.

20. Anon. A report on the survey of marine algal resources of Tamil Nadu. Central Salt and Marine Chemicals Research Institute, Bhavnagar; 1978. p. 137.

21. Kaliaperumal N. Seaweed resources and distribution in deep waters from Dhanushkodi to Kanyakumari, Tamilnadu. Seaweed Res Utiln 1998;20:141-1.

22. Anon. A report on the survey of marine algal resources of Tamil Nadu. Central Salt and Marine Chemicals Research Institute, Bhavnagar; 1984. p. 97.

23. Mitra C. Report on the development of Chilka Lake, Cuttack; 1946.

24. Rath J, Adhikari SP. Algal biomass of Chilka Lake, East coast of India. National Symposium and Exposition, Cochin, Abst; 2004. p. 24.

25. Anon. A report on the survey of marine algal resources of Lakshadweep, Central Salt and Marine Chemicals Research Institute, Bhavnagar; 1979. p. 48.

26. Muthuvelan B, Chennubhotla VS K, Nair KVK, Sampath V, Ravindran M. Standing crop biomass and comparative distribution of agarophytes, alginophytes and other algae in South Andaman. Indian Hydrobiol 2001;4:130-8.

27. Muthuvelan B, Chennubhotla VSK, Nair KVK, Sampath V, Ravindran M. Seaweed standing crop biomass and comparative distribution in the eastern shoreline of middle and North islands. Indian Hydrobiol 2001;4:139-8.

28. Gopinathan CP, Panigrahy R. Seaweed resources in mariculture potential of andaman and nicobar islands-an indicative survey. Bull CMFRI 1983;34:47-1.

29. Krishnamurthy V. Seaweed drift on the Indian coast. In: Proc Symp Indian Ocean Natl Inst Sci India 1969;38:657-6.

30. Dhargalkar VK, Deshmukhe GV. Subtidal marine algae of Dwarka coast (Gujarat). Indian J Mar Sci 1996;25:297-301.

31. Agadi VV. Distribution of marine algae in the littoral zone of Karnataka coast. In: Marine Plants. Seaweed Research Utilization Assoc Madras; 1985. p. 35-2.

32. Mukhopadhyay A, Pal R. A report on biodiversity of algae from coastal West Bengal (South and North 24-Parganas) and their cultural behaviour in relation to mass cultivation programme. Indian Hydrobiol 2002;5:97-107.

33. Sahoo D, Sahu N, Sahoo D. A critical survey of seaweed biodiversity of Chilika Lake, India. Algae 2003;18:1-12.

34. Ravindran VS, Thangaradjou T, Kannan L. Qualitative and quantitative distribution of seaweeds in the Great Nicobar Island. National Symposium and Exposition, Cochin, Abst; 2004. p. 27.

35. Mantri VA, Subba Rao PV. Diu Island: a paradise for tourists and seaweed biologists. Curr Sci 2005;89:1795-7.

36. Paul MA, Christopher IR Gill, Ross Campbell, Ian R Rowland. Nutritional value of edible seaweeds. International Life Sciences Institute. Special paper 2007;1:535-3. 
37. Kolanjinathan K, Ganesh P, Saranraj P. Pharmacological importance of seaweeds: a review. World J Fish Marine Sci 2014;6:1-15.

38. Parthiban C, Saranya C, Girija K, Hemalatha A, Suresh M, Anantharaman P. Biochemical composition of some selected seaweeds from Tuticorin coast. Adv Appl Sci Res 2013;4:362-6.

39. Chakraborty S, Santra SC. Biochemical composition of eight benthic algae collected from Sunderban. Indian J Marine Sci 2008;37:329-2.

40. Sobha V, Bindhu VK, Bindhu MS, Unnikrishnan P. Biochemical studies of algae along the Southern Kerala coast with special reference to fibre content. Seaweed Res Utiln 2001;23:65-3.

41. Manivannan K, Thirumaran G, Karthikai Devi G, Hemalatha A, Anantharaman P. Biochemical composition of seaweeds from mandapam coastal regions along the southeast coast of India, American-Eurasian. J Bot 2008;1:32-7.

42. Satpati G, Pal R. Biochemical composition and lipid characterization of marine green algae. JABV 2011;2:10-3.

43. Rajasulochana P, Krishnamoorthy P, Dhamotharan R. Biochemical investigation on red algae family of Kappahycus Sp. J Chem Pharm Res 2012;4:4637-1.

44. Michanek G. Getting seaweed to where it's needed. Ceres 1981;14:41-4.

45. Bonotto S. List of multicellular algae of commercial use. In: Marine Algae in Pharmaceutical Science; 1979. p. 121-7.

46. Hoppe HA. Marine algae and their products and constituents in pharmacy. In: Marine Algae in Pharmaceutical Science; 1979. p. 25-119.

47. Gross R, Gross U, Ramirez A, Cuadra K, Collazos C, Feldheim W. Nutritional tests with green alga Scenedesmus with healthy and malnourished persons. Arch Hydrobiol Beih 1978;11:161-3.

48. Pooja S. Algae used as medicine and food a short review. J Pharm Sci Res 2014;6:33-5.

49. Yuvaraj N, Arul V. In vitro antitumor, anti-inflammatory, antioxidant and antibacterial activities of marine brown alga Sargassum wightii collected from gulf of mannar. Global J Pharmacol 2014;8:566-7.

50. Richardson JS. Free radicals in the genesis of Alzheimer $s$ disease. Ann N Y Acad Sci 1993;695:73-6.

51. Jiménez-Escrig A, Sánchez-Muniz FJ. Dietary fibre from edible seaweeds: Chemical structure, physicochemical properties and effects on cholesterol metabolism. Nutr Res 2000;20:585-8.

52. Kolanjinathan K, Stella D. Pharmacological effect of Gracilaria corticata solvent extracts against human pathogenic bacteria and fungi. Int J Pharm Biol Arch 2011;2:1722-8.

53. Vijayabaskar P, Shiyamala V. Antibacterial activities of marine brown algae (Sargassum wightii and Turbinaria ornata) from the gulf of mannar biosphere reserve. Adv Biol Res 2011;5:99102.

54. Karthikaidevi G, Manivannan K, Thirumaran G, Anantharaman P, Balasubramanian T. Antibacterial properties of selected green seaweeds from vedalai coastal waters; the gulf of mannar marine biosphere reserve. Global J Pharmacol 2009;3:107-2.

55. Mohammed NA, Jae Suk Choi, Min Chul Lee, Eliya Kim, Taek Jeong Nam, Hitoshi Fujii, et al. Anti-inflammatory activities of methanol extracts from various seaweed species. J Environ Biol 2008;29:465-9.

56. Teas J. The consumption of seaweed as a protective factor in the aetiology of breast cancer. Med Hypotheses 1981;7:601-3.

57. Ghislain M, Kwak DH, Brice WO, Maranguy CA, Sylvatrie DB, Lee $\mathrm{DH}$, et al. Anticancer effects of different seaweeds on human colon and breast cancers. Marine Drugs 2014;12:4898-911.

58. Loeser AA. Hormones and breast cancer. Letters to the Editor, Lancet ii; 1956. p. 961.

59. Abirami RG, Kowsalya S. Antidiabetic activity of Ulva fasciata and its impact on carbohydrate enzymes in alloxan induced diabetic in rats. Int J Res Phytochem Pharmacol 2013;3:136-1.

60. Witvrouw M, Este JA, Mateu MQ, Reymen D, Andrei G, Snoeck R, et al. Activity of a sulfated polysaccharide extracted from the red seaweed Aghardhiella tenera against human immunodeficiency virus and other enveloped viruses. Antiviral Chem Chemother 1994;5:297-303.

61. Damonte EB, Neyts J, Pujol CA, Snoeck R, Andrei G, Ikeda S, et al. Antiviral activity of a sulphated polysaccharide from the red seaweed Nothogenia fastigiata. Biochem Pharmacol 1994;47:2187-2.

62. Kolender AA, Matulewicz MC, Cerezo AS. Structural analysis of antiviral sulfated $\alpha$-D-linked mannans. Carbohyd Res 1995;273:179-5.

63. Philpott Jane, Montse Bradford. Seaweed: Nature's Secret for a Long and Healthy Life? The Nutrition Practitioner; 2006. p. 121.

64. Glombitza KW. Antibiotics from algae. Marine Algae in Pharmaceutical Science; 1979. p. 303-2.

65. Waiter de Gruyter, Berlin Fenlcal W. Halogenation in the rhodophyta. A review. J Phycol 1975;11:245-9.

66. Hashimoto Y. Marine toxins and other bioactive marine metabolites. Japan Scientific Societies Press; Tokyo: 1979. p. 369.

67. Albertus J Smit. Medicinal and pharmaceutical uses of seaweed natural products: a review. J Appl Phycol 2004;16:245-2.

68. Nakamura $H$, Moriya $M$. Purification and partial characterization of a lectin-like protein from the sea algae Laminaria diabolica that induces fertilization envelope formation in sea urchin eggs. Zool Sci 1999;16:247-53.

69. Nomura K, Nakamura H, Suzuki N. False fertilization in sea urchin eggs induced by diabolin, a $120 \mathrm{~K}$ kelp protein. Biochem Biophys Res Comm 2000;273:691-3.

70. Premakumara GAS, Ratnasooriya WD, Tillekeratne LMV. Isolation of a non-steroidal contragestative agent from Sri Lankan marine red alga, Gelidiella acerosa. Contraception 1996;54:379-3.

71. Pesando D, Lem'ee R, Ferrua C, Amade P, Girard JP. Effects of caulerpenyne, the major toxin from Caulerpa taxifolia on mechanisms related to sea urchin egg cleavage. Aquat Toxicol 1996;35:139-5.

72. Pesando D, Huitorel P, Dolcini V, Amade P, Girard JP. Caulerpenyne interferes with microtubule-dependent events during the first mitotic cycle of sea urchin eggs. Eur J Cell Biol 1998;77:19-6.

73. Pedrotti ML, Lemee R. Effect of microalgae treated with natural toxins on the nutrition and development of filter-feeding seaurchin larvae. Mar Environ Res 1996;48:177-2.

74. Galgani I, Pesando D, Porthe-Nibelle J, Fossat B, Girard JP. Effect of caulerpenyne, a toxin extracted from Caulerpa taxifolia on mechanisms regulating intracellular $\mathrm{pH}$ in sea urchin eggs and sea bream hepatocytes. J Giochem Toxicol 1996;11:243-50.

75. Nisiwaza K. Pharmaceutical studies on marine algae in Japan. In: Marine Algae in Pharmaceutical Science; 1979. p. 243-4.

76. WHO Expert Committee. Control of Ascariasis. World Health Organization Technical Report Series; 1967. p. 379, 47.

77. Kashiwagi M, Mynderse JS, Moore RE, Norton TR. Antineoplastic evaluation of pacific basin marine algae. J Pharm Sci 1980;69:734-8.

78. Kulandhaisamy AS, Annappan M. Antiulcer, wound healing and hepatoprotective activities of the seaweeds Gracilaria crassa, Turbinaria ornata and Laurencia papillosa from the southeast coast of India. Brazilian J Pharm Sci 2013;49:669-8.

79. Michanek G. Seaweed resources for pharmaceutical uses. In: Marine Algae in Pharmaceutical Science; 1979. p. 203-5.

80. CMFRI. Special publication. Economically Important Seaweeds 1995;62:36

81. Subbaramaiah. Seaweed resources and distribution in India. National Symposium and Exposition-Souvenir; 2004. p. 64.

82. Krishnamurthy V. Seaweeds wonder plants of the sea; 2005. p. 30.

83. Dhargalkar VK, Neelam Pereira. Seaweed: promising plant of the millennium. Sci Culture 2005;71:60-6.

84. CMFRI. Socio-economic dimensions of seaweed farming in India. Special Publication; 2010. p. 104.

85. Chapman VJ, Champan DJ. Seaweed and their uses. 3rd Edition. Chapman and Hall, New York; 1980. p. 63-5.

86. Kaladharan P, Kaliaperumal N, Ramalingam JR. Marine fishery information series. Mar Fish Inf Ser 1998;157:1-10.

87. Sasikumar C, Rengsamy R. Role of red alga Hypnea valentiae (Gigartinales, Rhodophyta) in domestic effluent treatment at different light intensity and quality. Indian J Mar Sci 1994;23:162-4. 
88. Ramani Gade, Tulasi M Siva, Aruna Bhai V. Seaweeds: a novel biomaterial. Int J Pharm Pharm Sci 2013;5:40-4.

89. Mohammed AA. In vitro antibacterial, antifungal, antibiofilm and antioxidant potentials of isopimpinellin recovered from Citrullus colocynthis. Int J Pharm Pharm Sci 2016;8:117-2.

90. Kanimozhi AS, Johnson M, Malar T Renisheya. Phytochemical composition of Sargassum Polycystum C Agardh and Sargassum Duplicatum J Agardh. Int J Pharm Pharm Sci 2015;7:393-7.
91. Tyagi Richa, Sharma Gaurav, Jasuja Nakuleshwar Dut, Menghani Ekta. Indian medicinal plants as an effective antimicrobial agent. J Crit Rev 2016;3:69-71.

\section{How to cite this article}

- Mitali Priyadarsini Pati, Satyabrata Das Sharma, Lakshman Nayak, Chita Ranjan Panda. Uses of seaweed and its application to human welfare: a review. Int J Pharm Pharm Sci 2016;8(10):12-20. 